LA-7307-MS Informal Report

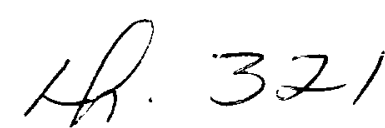

$8 \cdot 3 \cdot 78$
UC-11

Issued: May 1978

\title{
Water Quality in Vicinity of Fenton Hill Site, 1976
}

W. D. Purtymun

W. H. Adams

A. K. Stoker

An Alfirmative Action/Equal Opportunity Employer 


\section{DISCLAIMER}

This report was prepared as an account of work sponsored by an agency of the United States Government. Neither the United States Government nor any agency Thereof, nor any of their employees, makes any warranty, express or implied, or assumes any legal liability or responsibility for the accuracy, completeness, or usefulness of any information, apparatus, product, or process disclosed, or represents that its use would not infringe privately owned rights. Reference herein to any specific commercial product, process, or service by trade name, trademark, manufacturer, or otherwise does not necessarily constitute or imply its endorsement, recommendation, or favoring by the United States Government or any agency thereof. The views and opinions of authors expressed herein do not necessarily state or reflect those of the United States Government or any agency thereof. 


\section{DISCLAIMER}

Portions of this document may be illegible in electronic image products. Images are produced from the best available original document. 
Printed in the United States of Americu. Available from National Technical Information Service

U.S. Department of Commerce

5285 Port Ruyal Roud

Springtield. VA 2216

Microfiche $\$ 3.00$

$\begin{array}{llllllllll}00+-025 & 4.00 & 126-150 & 7.25 & \mathbf{2 5 1} 1.275 & 10.75 & 376-400 & 13.00 & 501-525 & 15.25 \\ 026-050 & 4.50 & 151-175 & 8.04 & 276-300 & 11.00 & 401-425 & 13.25 & 526-550 & 15.50 \\ \mathbf{0 5 1} 1-075 & 5.25 & 176-200 & \mathbf{9 . 0 0} & \mathbf{3 0 1} 1-325 & 11.75 & \mathbf{4 2 6 - 4 5 0} & \mathbf{1 4 . 0 0} & 551-575 & 16.25 \\ 076-100 & \mathbf{6 . 0 0} & \mathbf{2 0 1 . 2 2 5} & \mathbf{9 . 2 5} & \mathbf{3 2 6 - 3 5 0} & 12.00 & \mathbf{4 5 1 - 4 7 5} & 14.50 & 576-600 & 16.50 \\ 101-125 & \mathbf{6 . 5 0} & 226-250 & \mathbf{9 . 5 0} & 351-375 & 12.50 & \mathbf{4 7 6 - 5 0 0} & \mathbf{1 5 . 0 0} & 601-\mathrm{up} & --1\end{array}$

1. Add $\$ 2.50$ for each additional 100-page increment from 601 pages up.

This report was prepared as an account of work sponsored by the United States Government. Neither the United States nor the United States Department of Energy, nor any of their employees, nor any of their contractors, subcontractors. or their employees, makes any warranty, express or implied, or assumes any legal habilty or responsibitty for the accuracy. completeness, or usefulness of any information, apparatus, product, or process disclosed. or represents that its use would 
WATER QUALITY IN VICINITY OF FENTON HILL SITE, 1976

by

\author{
W. D. Purtymun \\ W. H. Adams \\ A. K. Stoker
}

\begin{abstract}
Water quality data have been collected at 9 surface-water stations, 11 ground-water stations, and 3 ponds at the Fenton Hill Geothermal Site in the Jemez Mountains. This is part of the Los Alamos Scientific Laboratory's continuing program of environmental studies. Insignificant changes (within expected normal seasonal fluctuations) in the chemical quality of water at individual stations were observed during the year. Predominant ions and total dissolved solids remained essentially stable.
\end{abstract}

\section{INTRODUCTION}

Base-line water quality studies of the Jemez River and Rio Guadalupe drainage areas, based on field investigations and a literature search, were made in 1973 before any Los Alamos Scientific Laboratory (LASL) experimental work at the Fenton Hill Site (TA-57). ${ }^{1}$ Additional quality data were reported in 1974 and $1975 .^{2,8}$ The water quality data for 1976 are presented in this report.

The Fenton Hill Site, location of the LASL hot dry rock geothermal experiment, is bounded on the east by San Antonio Creek and on the west and northwest by the Rio Cebolla (Fig. 1). Lake Fork Canyon, to the south, drains the immediate area of the site and is tributary to the Rio Cebolla. Lake Fork Canyon and an unnamed canyon to the north of the site have only intermittent streams.

Preliminary geologic and hydrologic investigations were made in conjunction with test drilling at TA-57 and in the adjacent area. These investigations provided a basis for selecting the locations for the water quality monitoring stations. ${ }^{4,6}$ The discussion of surface-and ground-water quality is organized according to groups of predominant ions and total dissolved solids (TDS). The annual mean concentration and standard deviation of principal ions and TDS for a number of analyses at individual stations are compared for 1974,1975 , and 1976 . The variation $( \pm)$ from the annual mean does not indicate the precision of individual analyses, but rather the deviation of the distribution of the several analyses at a single station.

\section{WATER QUALITY}

Routine chemical analyses were made for silica, calcium, magnesium, sodium, carbonate, bicarbonate, sulfate, chloride, nitrate, fluoride, total hardness, TDS, conductance, and $\mathrm{pH}$. The analytical methods are described in Ref. 6. Samples were collected during three periods in April, August, and November 1976. Specific ion analyses for 


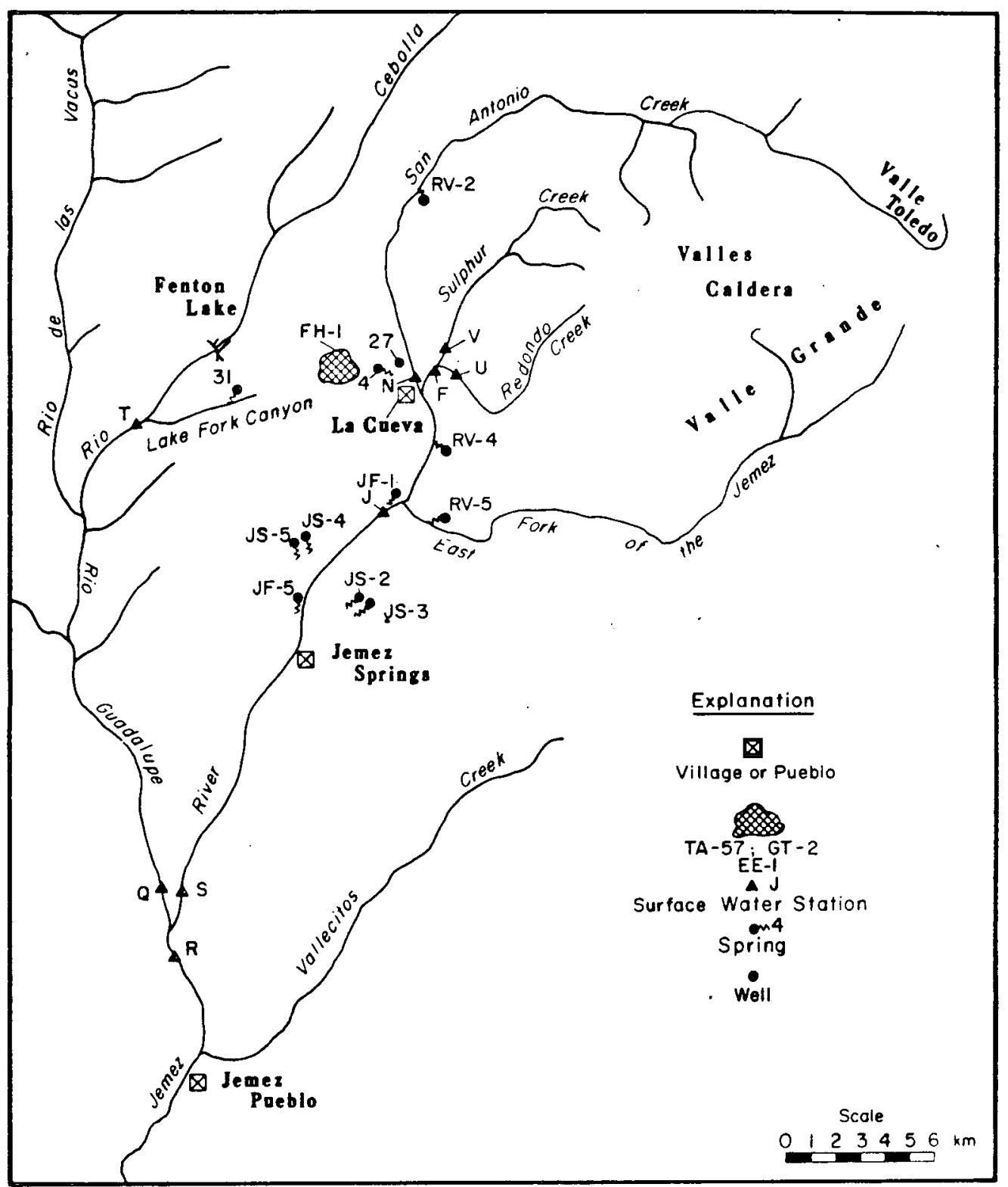

Fig. 1.

Location of sampling stations.

$\begin{array}{ll}\text { F } & \text { Sulphur Creek } \\ \text { J } & \text { Jemez River } \\ \text { N } & \text { San Antonio Creek } \\ \text { Q } & \text { Rio Guadalupe } \\ \text { R } & \text { Jemez River } \\ \text { S } & \text { Jemez River } \\ \text { T } & \text { Rio Cebolla } \\ \text { U } & \text { Redondo Creek } \\ \text { V } & \text { Sulphur Creek } \\ \text { JS-2, }-3 & \text { Jemez Springs water supply }\end{array}$

$\begin{array}{ll}\text { JS-4, -5 } & \text { Jemez Springs water supply } \\ 4 & \text { La Cueva water supply } \\ \text { JF-1 } & \text { Limestone Spring } \\ \text { JF-5 } & \text { Soda Dam } \\ 27 & \text { Hofheins Flowing Well } \\ 31 & \text { Cold Spring } \\ \text { RV-2 } & \text { San Antonio Hot Spring } \\ \text { RV-4 } & \text { Spence Spring } \\ \text { RV-5 } & \text { McCauley Spring } \\ \text { FH-1 } & \text { Water supply TA-57 }\end{array}$


numerous metal ions were made of pond water taken from the site.

\section{A. Surface Water}

Surface water in the tributaries to the Jemez River (Redondo, Sulphur, and San Antonio Creeks) is monitored to see if there is any detectable effect on the quality of these waters by the geothermal explorations and testing in the area. The Rio Cebolla below Lake Fork Canyon and the Rio Guadalupe above the Jemez River are monitored because of the contributions of ground water from the volcanic rocks underlying the Fenton Hill Site and surface runoff from the site.

Analyses were made of surface water from nine stations along the Jemez River, the Rio Guadalupe, and their tributaries. Discharge measurements were estimated at the time the samples were collected. The station locations (identified by capital letters in Fig. 1) are keyed to analyses presented in Appendix A. The base flow of these streams is principally from the shallow ground water system in the Valles Caldera, from perched aquifers in the volcanics, and from thermal or mineral springs. Each base flow source has a characteristic chemical quality that may be modified by precipitation run-off. Thus the chemical quality of water from a particular station can vary widely, reflecting changes in discharges caused by the amount of precipitation in the drainage area. There are four general types of surface water in the drainage areas, based on predominant ions: (1) sodium and chloride, (2) calcium and sulfate, (3) calcium and bicarbonate, and (4) sodium and bicarbonate.

The principal ions in the base flow and run-off at Locations $U, R$, and $S$ are sodium and chloride (Table I). Location U is on Redondo Creek, which drains a small basin in the caldera where geothermal exploration is in progress. The discharge at this station ranged from 5 to $30 \mathrm{l} / \mathrm{s}$ during our sampling periods, with water temperatures ranging from $0^{\circ}$ to $12^{\circ} \mathrm{C}$. There was no significant change in the average mean concentrations of sodium and chloride, but the total dissolved solids increased slightly in 1976 in comparison to 1975 (Table I).

Location $R$ is on the Jemez River below the confluence of the Rio Guadalupe, which drains an area of about $1220 \mathrm{~km}^{2}$, including the Valles Caldera and an adjacent mountain area to the west. The stream discharge at this station ranged from about 200 to $1000 \mathrm{l} / \mathrm{s}$. Water temperatures ranged from $6^{\circ}$ to $21^{\circ} \mathrm{C}$. There was no significant change in sodium, chloride, or TDS from 1975 to 1976.

\section{TABLE I}

\section{COMPARISON OF SODIUM (Na), CHLORIDE (CI), AND TOTAL DISSOLVED SOLIDS (TDS) AT SURFACE WATER STATIONS U, R, AND S $1974-1976$}

\begin{tabular}{|c|c|c|c|c|}
\hline Year & Constituent & $\begin{array}{c}\text { U } \\
\text { (Redondo Creek) }\end{array}$ & $\begin{array}{c}\text { R } \\
\text { (Jemez River) }\end{array}$ & $\begin{array}{c}\text { S } \\
\text { (Jemez River) }\end{array}$ \\
\hline 1974 & $\mathrm{Na}$ & 40 & $60( \pm 32)$ & $84( \pm 41)$ \\
\hline 1975 & $\mathrm{Na}$ & $12( \pm 3)$ & $53( \pm 34)$ & $63( \pm 32)$ \\
\hline 1976 & $\mathrm{Na}$ & $17( \pm 6)$ & $55( \pm 20)$ & $70( \pm 16)$ \\
\hline 1974 & $\mathrm{Cl}$ & 94 & $76( \pm 45)$ & $116( \pm 56)$ \\
\hline 1975 & $\mathrm{Cl}$ & $27( \pm 11)$ & $65( \pm 46)$ & $81( \pm 40)$ \\
\hline 1976 & $\mathrm{Cl}$ & $46( \pm 21)$ & $68( \pm 21)$ & $71( \pm 20)$ \\
\hline 1974 & TDS & 312 & $411 \quad(99)$ & $483( \pm 144)$ \\
\hline 1975 & TDS & $149( \pm 22)$ & $349( \pm 127)$ & $376( \pm 120)$ \\
\hline 1976 & TDS & $223( \pm 31)$ & $384( \pm 90)$ & $385( \pm 84)$ \\
\hline
\end{tabular}

This report was prepared as an account of work sponsored by the United States Government. Neither the United States nor the United States Department of Energy, nor any of their employees, nor any of their contractors, subcontractors, or their employes, makes any warranty, express or implied, or assumes any lega libily or responsibility ior or usefulnes of any in formation, appar,

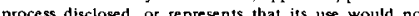
infringe privately owned rights.

\section{$\mathbf{U}$}


Location $\mathrm{S}$ is on the Jemez River above the confluence with the Rio Guadalupe, where the flow is from the Valles Caldera. The discharge at this station ranged from 140 to $550 \mathrm{l} / \mathrm{s}$. Water temperatures ranged from $7^{\circ}$ to $14^{\circ} \mathrm{C}$. There was no significant change in sodium, chloride, or TDS from 1975 to 1976.

The principal ions in base flow at Locations $\mathrm{N}, \mathrm{T}$, and $\mathrm{Q}$ are calcium and bicarbonate (Table II). Location $\mathrm{N}$ is on San Antonio Creek, which drains the western and northern parts of the Valles Caldera. The discharge at the station ranged from 75 to 350 $\ell / \mathrm{s}$, with water temperature ranging from $0^{\circ}$ to $14^{\circ} \mathrm{C}$. There was no significant change in calcium, bicarbonate, or total dissolved solids concentrations from 1975 to 1976.

Location $\mathrm{T}$ is on the Rio Cebolla, which drains the mountain flanks west of the caldera (Fig. 1). The discharge ranged from 85 to $225 \mathrm{l} / \mathrm{s}$, with water temperatures that ranged from $7^{\circ}$ to $18^{\circ} \mathrm{C}$. There was no significant change in calcium, bicarbonate, or TDS from 1975 to 1976.

Location $\mathrm{Q}$ is on the Rio Guadalupe, which drains the flanks of the mountains west of the caldera and the Rio Cebolla. The discharge at this station ranged from 55 to $420 \mathrm{l} / \mathrm{s}$. Water temperature ranged from $6^{\circ}$ to $20^{\circ} \mathrm{C}$. There was no significant change in calcium, bicarbonate, or TDS from 1975 to 1976 (Table II).

The principal ions in base flow at Locations $\mathrm{V}$ and $\mathrm{F}$ are calcium and sulfate (Table III). Location $\mathrm{V}$ is on Sulphur Creek, which drains a small interior basin in the Valles Caldera to the east of the Redondo Creek drainage basin. The basin contains mineral and thermal springs that result in an entirely different type of water than found in the Redondo drainage. The discharge at Location $V$ ranged from 2 to $50 \mathrm{l} / \mathrm{s}$. Water temperatures were low, ranging from $4^{\circ}$ to $11^{\circ} \mathrm{C}$, due to the low discharge rate and distance from the thermal springs. There was no significant change in calcium, sulfate, or total dissolved solids from 1975 to 1976 .

Location $\mathrm{F}$ is on Sulphur Creek at a point below the confluence of Redondo and Sulphur Creeks and just above the confluence with San Antonio Creek (Fig. 1). The discharge at the station ranged from 6 to $100 \mathrm{l} / \mathrm{s}$. Water temperatures ranged from $0^{\circ}$ to $11^{\circ} \mathrm{C}$. The mean concentrations of calcium and sulfate increased, with no significant change in TDS in 1976 when compared to 1975 (Table III).
The principal ions in the base flow at Location $\mathrm{J}$ are sodium and bicarbonate (Table IV). Location $\mathrm{J}$ is on the Jemez River below the confluence of the East Fork of the Jemez River and San Antonio Creek (Fig. 1). The drainage area includes the combined basins within the Valles Caldera. The discharge at the station ranged from 225 to $550 \mathrm{l} / \mathrm{s}$. Water temperatures ranged from $3^{\circ}$ to $15^{\circ} \mathrm{C}$. There was an insignificant increase in the mean concentrations of sodium, bicarbonate, and TDS in 1976 when compared to 1975 .

\section{B. Ground Water}

Ground water samples were collected from the water supply for the communities of Jemez Springs (four sources) and La Cueva (one source), and three springs and one well adjacent to the Fenton Hill Site. Additional samples were collected, before and after completion of drilling, from a well which furnishes water to TA-57. Three thermal springs also were sampled during August 1976. Station locations are shown by capital letters followed by a number, or by a number alone, on Fig. 1, and are keyed to analyses presented in Appendix B.

Three types of ground-water, categorized by principal ions, occur at these ground water stations. For this discussion, the principal ion groups are (1) sodium and bicarbonate, (2) sodium chloride, and (3) calcium bicarbonate.

The predominant ions at Locations JS-2, -3, -4, and -5 are sodium and bicarbonate (Table V). The water supply for the village of Jemez Springs is from these four springs that discharge from the volcanic rocks overlying sediment along the walls of Jemez Canyon. Springs JS-2 and -3, flow from the east and west forks of Church Canyon, respectively; the latter being a minor canyon tributary to the Jemez River. The village distribution system samples represent the combined flow from these two springs. Temperatures ranged from $8^{\circ}$ to $20^{\circ} \mathrm{C}$. Springs JS -4 and JS-5 are located on the west side of Jemez Canyon north of the village (Fig. 1). The samples collected at the north end of the village at the Jemez District Forest Service Headquarters represent the combined flow from these two springs. Water temperatures ranged from $14^{\circ}$ to $25^{\circ} \mathrm{C}$ at the sampling point. There was no significant change in the 
TABLE II

COMPARISON OF CALCIUM (Ca), BICARBONATE $\left(\mathrm{HCO}_{3}\right)$, AND

TOTAL DISSOLVED SOLIDS (TDS)

AT SURFACE WATER STATIONS N, T, AND Q

$1974-1976$

(in $\mathrm{mg} / \mathrm{l}$ )

\begin{tabular}{|c|c|c|c|c|}
\hline Year & Constituent & $\frac{\mathrm{N}}{\text { (San Antonio Creek) }}$ & $\begin{array}{c}\mathrm{T} \\
\text { (Rio Cebolla) }\end{array}$ & $\begin{array}{c}\text { Q } \\
\text { (Rio Guadalupe) }\end{array}$ \\
\hline 1974 & $\mathrm{Ca}$ & $16( \pm 3)$ & $21( \pm 2)$ & $54( \pm 8)$ \\
\hline 1975 & $\mathrm{Ca}$ & $13( \pm 6)$ & $17( \pm 3)$ & $38( \pm 14)$ \\
\hline 1976 & $\mathrm{Ca}$ & $15( \pm 2)$ & $18( \pm 2)$ & $39( \pm 10)$ \\
\hline 1974 & $\mathrm{HCO}_{3}$ & $70( \pm 16)$ & $88( \pm 4)$ & $187( \pm 34)$ \\
\hline 1975 & $\mathrm{HCO}_{3}$ & $69( \pm 10)$ & $65( \pm 13)$ & $129( \pm 53)$ \\
\hline 1976 & $\mathrm{HCO}_{3}$ & $63( \pm 12)$ & $79( \pm 2)$ & $127( \pm 45)$ \\
\hline 1974 & TDS & $190( \pm 31)$ & $160( \pm 14)$ & $292( \pm 73)$ \\
\hline 1975 & TDS & $159( \pm 31)$ & $123( \pm 25)$ & $170( \pm 16)$ \\
\hline 1976 & TDS & $165( \pm 17)$ & $129( \pm 4)$ & $182( \pm 66)$ \\
\hline
\end{tabular}

TABLE III

COMPARISON OF CALCIUM (Ca), SULFATE ( $\left.\mathrm{SO}_{4}\right)$, AND

TOTAL DISSOLVED SOLIDS (TDS)

AT SURFACE WATER STATIONS V AND F

$1974-1976$

(in $\mathbf{m g} / \mathbf{l}$ )

\begin{tabular}{|c|c|c|c|}
\hline Year & Constituent & $\begin{array}{c}\text { V } \\
\text { (Sulphur Creek) }\end{array}$ & $\begin{array}{c}\text { F } \\
\text { (Sulphur Creek) }\end{array}$ \\
\hline 1974 & $\mathrm{Ca}$ & 90 & $43( \pm 8)$ \\
\hline 1975 & $\mathrm{Ca}$ & $57( \pm 31)$ & $30( \pm 5)$ \\
\hline 1976 & $\mathrm{Ca}$ & $74( \pm 24)$ & $46( \pm 9)$ \\
\hline 1974 & $\mathrm{SO}_{4}$ & 364 & $120( \pm 41)$ \\
\hline 1975 & $\mathrm{SO}_{4}$ & $248( \pm 133)$ & $48( \pm 20)$ \\
\hline 1976 & $\mathrm{SO}_{4}$ & $292( \pm 78)$ & $133( \pm 28)$ \\
\hline 1974 & TDS & 680 & $338( \pm 75)$ \\
\hline 1975 & TDS & $440( \pm 204)$ & $212( \pm 40)$ \\
\hline 1976 & TDS & $527( \pm 200)$ & $204( \pm 58)$ \\
\hline
\end{tabular}


TABLE IV

COMPARISON OF SODIUM (Na), BICARBONATE (HCOs), AND TOTAL DISSOLVED SOLIDS (TDS) AT SURFACE WATER STATION J $1974-1976$

(in $\mathbf{m g} / \ell$ )

\begin{tabular}{|c|c|c|}
\hline Year & Constituents & $\begin{array}{c}J \\
\text { (Jemez River) }\end{array}$ \\
\hline 1974 & $\mathrm{Na}$ & $18( \pm 8)$ \\
\hline 1975 & $\mathrm{Na}$ & $12( \pm 4)$ \\
\hline 1976 & $\mathrm{Na}$ & $16( \pm 4)$ \\
\hline 1974 & $\mathrm{HCO}_{3}$ & $69( \pm 19)$ \\
\hline 1975 & $\mathrm{HCO}_{2}$ & $53( \pm 13)$ \\
\hline 1976 & $\mathrm{HCO}_{2}$ & $64(\star 12)$ \\
\hline 1974 & TDS & $174( \pm 37)$ \\
\hline 1975 & TDS & $129( \pm 27)$ \\
\hline 1976 & TDS & $160( \pm 13)$ \\
\hline
\end{tabular}

TABLE V

COMPARISON OF SODIUM (Na), BICARBONATE $\left(\mathrm{HCO}_{3}\right)$, AND TOTAL DISSOLVED SOLIDS (TDE) AT GROUND WATER STATIONS JS-2-3, JS-4-5, 4, 27, 31, RV - 2, -4, AND -5

$184-187$

(1) $m$ /

\begin{tabular}{|c|c|c|c|c|c|c|c|c|c|}
\hline Year & Constituent & $\begin{array}{c}\text { JS-2,-3 } \\
\text { (WS } \\
\text { Jemez } \\
\text { Spr) }\end{array}$ & $\begin{array}{c}\text { JS-4,-5 } \\
\text { (WS } \\
\text { Jemez } \\
\text { Spr) }\end{array}$ & (1) & 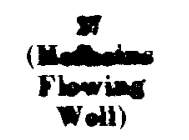 & $\begin{array}{c}31 \\
\text { (Cold Spr) }\end{array}$ & 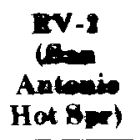 & $\underset{n}{w^{N-4}}$ & 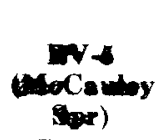 \\
\hline 1974 & $\mathrm{Na}$ & $18( \pm 1)$ & $16( \pm 2)$ & $17( \pm 2)$ & 141 & $17( \pm 4)$ & & & \\
\hline 1975 & $\mathrm{Na}$ & $13( \pm 1)$ & $13( \pm 1)$ & $15( \pm 2)$ & $113( \pm 10)$ & $12( \pm 2)$ & 22 & $( \pm 0)$ & $20(\$ 1)$ \\
\hline 1976 & $\mathrm{Na}$ & $16( \pm 1)$ & $14( \pm 1)$ & $16( \pm 1)$ & $114(\neq 14)$ & $11( \pm 1)$ & 2 & $\omega$ & 10 \\
\hline 1974 & $\mathrm{HCO}_{s}$ & $84( \pm 5)$ & $89( \pm 23)$ & $74( \pm 4)$ & 144 & $6 \theta( \pm 5)$ & & & \\
\hline 1975 & $\mathrm{HCO}_{s}$ & $68( \pm 5)$ & $75( \pm 1)$ & $63( \pm 6)$ & $394( \pm 15)$ & $60( \pm 4)$ & 56 & $124( \pm 6)$ & $75( \pm 1)$ \\
\hline 1976 & $\mathrm{HCO}_{3}$ & $69( \pm 1)$ & $71( \pm 1)$ & $66( \pm 2)$ & $367( \pm 15)$ & $62( \pm 5)$ & 48 & 120 & $\boldsymbol{m}$ \\
\hline 1974 & TDS & $214( \pm 31)$ & $169( \pm 17)$ & $181( \pm 23)$ & 576 & $201( \pm 67)$ & & & \\
\hline 1975 & TDS & $144( \pm 37)$ & $172( \pm 25)$ & $155( \pm 22)$ & $510( \pm 31)$ & $125( \pm 15)$ & 166 & $250( \pm 11)$ & $151( \pm 4)$ \\
\hline 1976 & TDS & $165( \pm 3)$ & $178( \pm 5)$ & $154( \pm 27)$ & $444( \pm 70)$ & $135( \pm 8)$ & 142 & 29 & 149 \\
\hline
\end{tabular}


average concentrations of sodium, bicarbonate, or TDS in any of these samples, from 1975 to 1976 (Table V).

The principel ions at Location 4 (Horseshoe Spring), which contribute to the water supply for La Cueva, are sodium and bicarbonate. The spring discharges at the base of volcanic rocks west of the village. The water temperature ranged from $15^{\circ}$ to $17^{\circ} \mathrm{C}$. There was no significant change in predominant ions or in TDS from 1975 to 1976.

The principal ions at Location 27 (Hofheins Flowing Well) were also sodium and bicarbonate (Table V). This well, located near San Antonio Creek at La Cueva, is completed in the sediments of the Abo Formation, and the water is highly mineralized when compared to the water from volcanic rocks, as at Location 4 . The water at the well is under artesian pressure and is not used for domestic purposes. Water temperatures ranged from $16^{\circ}$ to $22^{\circ} \mathrm{C}$. There was no significant change in principal ions from 1975 to 1976 (Table V); however, the average TDS decreased slightly in 1976.

The principal ions at Location 31 (Cold Spring) were sodium and bicarbonate (Table $\mathrm{V}$ ). The spring is located near the mouth of Lake Fork Canyon, down gradient from TA-57 (Fig. 1). It is a small spring-and-seep area that discharges near the base of the volcanic rocks that underlie the site. The water temperatures ranged from $10^{\circ}$ to $11^{\circ} \mathrm{C}$. There was no significant change in principal ions or TDS from 1975 to 1976.

The principal ions in water from the thermal springs at Locations RV-2 (San Antonio Hot Spring), RV-4 (Spence Spring), and RV-5 (McCauley Spring) are also sodium and bicarbonate. These springs discharge from recent volcanic rocks. Water temperatures at the three springs ranged from $31^{\circ}$ to $40^{\circ} \mathrm{C}$. There was no significant change in principal ions in water from any of these springs from 1975 to 1976 (Table V). TDS decreased slightly at RV-2 and RV-5 and increased slightly at RV-4 in 1976; however, these differences may be the result of collecting the samples from slightly different locations in 1976 .

A supply well at TA-57 (Location FH-1) was completed and caned to depth of $137 \mathrm{~m}$, in volcanic rock, in Juhy 1076. A mater sample was collected at a depth of $116.8 \mathrm{~m}$, when water was first encouncered during dridling (Appendix B). Analyses indicated that TDS were high $(344 \mathrm{mg} / \ell)$ for water in the volcanic rock in the area. The sample was contaminated with drilling mud used to stabilize the hole during construction. After completion, the well was tested for a $24-\mathrm{h}$ period, at a pumping rate of about $1.9 \ell / \mathrm{s}$, on July 26 and 27 . Water samples were collected during the test. TDS ranged from 98 to 199 $\mathrm{mg} / \mathrm{l}$ during the first $10 \mathrm{~h}$ of the test and then stabilized at about 102 to $104 \mathrm{mg} / \mathrm{l}$ during the remainder of the test. The water level remained constant at about $109.7 \mathrm{~m}$ during the $24 \mathrm{~h}$ of pumping. Water temperature was about $32.2^{\circ} \mathrm{C}$ at the start of the test, decreasing to about $23.9^{\circ} \mathrm{C}$ at the end of 24 h. The temperature increased from $23.9^{\circ} \mathrm{C}$ on July 27 to $26.4^{\circ} \mathrm{C}$ on September 15, during which time the well was not pumped. The slight variations in chemical constituents that occurred during the test, along with changes in water temperatures, indicate that the well penetrated two zones of water with slightly different chemical characteristics and temperatures.

The water from $\mathrm{FH}-1$ contains calcium and bicarbonate as principal ions. A sample taken in November 1976 contained $31 \mathrm{mg} / \ell$ calcium, 107 $\mathrm{mg} / \ell$ bicarbonate, $202 \mathrm{mg} / \ell \mathrm{TDS}$, and $99 \mathrm{mg} / \ell$ total hardness. The silicate $(70 \mathrm{mg} / \ell)$, calcium, and magnesium ( $4 \mathrm{mg} / \mathrm{l})$ will probably cause some scale formation in the distribution system if the water is heated for use.

The principal ions in water from Locations JF-1 (Limestone Spring) and -5 (Soda Dam) were sodium and chloride, JF-1 and -5 are thermal and mineral springs that discharge from the Jemez Fault (Fig. 1).

The water from JF-1 reaches a temperature 16 to $17^{\circ} \mathrm{C}$ and discharge at a rate of $<1 \mathrm{l} / \mathrm{s}$. A series of thermal and mineral springs at JF-5 has formed a large deposit of tufa extending outward from the west wall of the canyon into the stream, hence the name Soda Dam. The flow at the sampling location was about $1 \mathrm{l} / \mathrm{s}$, with combined spring discharge in the area of about $40 \mathrm{l} / \mathrm{s}$. Water temperatures ranged from $46^{\circ}$ to $47^{\circ} \mathrm{C}$ at the times of sample collection in 1976. The principal ions, sodium and chloride, in waters from JF-1 and JF-5, increased slightly; TDS increased at JF-1 and decreased at JF-5 in 1976 when compared to 1975 (Table VI). These variations orcur seasonally and are not significant. 


\section{TABLE VI}

\section{COMPARISON OF SODIUM (Na), CHLORIDE (Cl), AND TOTAL DISSOLVED SOLIDS (TDS) \\ FROM GROUND WATER STATIONS JF-1 AND JF-5 \\ $1974-1976$}

(in $\mathrm{mg} / \mathrm{l}$ )

\begin{tabular}{|c|c|c|c|}
\hline Year & Constituent & $\begin{array}{c}\text { JF-1 } \\
\text { (Limestone Spring) }\end{array}$ & $\begin{array}{c}\text { JF-5 } \\
\text { (Soda Dam) }\end{array}$ \\
\hline 1974 & $\mathrm{Na}$ & $260( \pm 50)$ & $772( \pm 171)$ \\
\hline 1975 & $\mathrm{Na}$ & $198( \pm 69)$ & $837( \pm 85)$ \\
\hline 1976 & $\mathrm{Na}$ & $292( \pm 80)$ & $895( \pm 252)$ \\
\hline 1974 & $\mathrm{Cl}$ & $378( \pm 58)$ & $1470( \pm 20)$ \\
\hline 1975 & $\mathrm{Cl}$ & $305( \pm 100)$ & $1360( \pm 11)$ \\
\hline 1976 & $\mathrm{Cl}$ & $329( \pm 81)$ & $1400( \pm 70)$ \\
\hline 1974 & TDS & $1260( \pm 119)$ & $3950( \pm 36)$ \\
\hline 1975 & TDS & $1110( \pm 170)$ & $3600( \pm 172)$ \\
\hline 1976 & TDS & $1171( \pm 79)$ & $3381( \pm 154)$ \\
\hline
\end{tabular}

\section{Quality of Water at Ponds (TA-57)}

tinuous irrigation and livestock, and the EPA Interim Primary Standards for drinking water (Table VII) ${ }^{7,8}$ The exceptions to proposed standards

Water used for experiments in Test Holes GT-2 and EE- 1 is stored in three ponds at TA-57. The ponds were sampled in August and November 1976; the analyses are shown in Appendix C. The quality of water in these ponds changes rapidly, depending on the types of experiments being performed. Water is circulated through the fracture in the granitic rock between Test Holes EE-1 and GT-2, a depth of about $3000 \mathrm{~m}$. The average TDS concentration decreased about $950 \mathrm{mg} / \ell$, from 1350 to $400 \mathrm{mg} / \ell$, in the upper and middle ponds between August and November. During this same period, the total dissolved solids in the lower pond increased about 1400 $\mathrm{mg} / \ell$, from $1600 \mathrm{mg} / \ell$ to $3000 \mathrm{mg} / \ell$.

When the lower pond was drained, the water was passed through columns of activated alumina and charcoal to remove fluoride and some organic dyes. The quality of water released from the lower pond (GTP-3) generally met the criteria proposed by the Environmental Protection Agency (EPA) for confor continuous irrigation were boron and lithium concentrations. Trace element analyses of water circulated though the energy extraction holes and ponds are shown in Appendix D. The water was released slowly into an adjacent dry canyon south of the site, which is a tributary to Lake Fork Canyon. With the slow release, the water infiltrated completely into the dry stream bed of this canyon within $300 \mathrm{~m}$ of the site. Water is released from the ponds under controlled conditions, with chemical quality corrective treatment performed prior to release if necessary. Before release, final approval is obtained from the US Forest Service.

\section{SUMMARY}

The quality of surface water from the Jemez River and Rio Guadalupe drainage areas varied during 1976 at individual stations. However, the variations 
TABLE VII

\section{COMPARISON OF TRACE ELEMENT CONCENTRATIONS OF WATER RELEASED FROM LOWER POND (GTP-3) WITH ENVIRONMENTAL PROTECTION AGENCY \\ PROPOSED STANDARDS FOR IRRIGATION AND LIVESTOCK USE AND INTERIM PRIMARY STANDARDS FOR DRINKING WATER}

(in $\mathbf{m g} / \ell$ )

\begin{tabular}{|c|c|c|c|c|}
\hline \multirow[b]{2}{*}{$\begin{array}{c}\text { Trace } \\
\text { Elements }\end{array}$} & \multicolumn{4}{|c|}{ Proposed Standards } \\
\hline & $\begin{array}{c}\text { Release } \\
\text { Lower Pond } \\
\text { (GTP-3) }\end{array}$ & $\begin{array}{l}\text { Continuous } \\
\text { Irrigation }\end{array}$ & Livestock & $\begin{array}{c}\text { Drinking } \\
\text { Water } \\
\text { Standards }\end{array}$ \\
\hline Aluminum & 2 & 5 & 5 & $\ldots$ \\
\hline Arsenic & $<0.5$ & 0.1 & 0.2 & 0.05 \\
\hline Beryllium & $<0.01$ & 0.1 & -- & -- \\
\hline Boron & 5 & 0.75 & 5. & $\ldots$ \\
\hline Cadmium & $<1$ & 0.01 & 0.05 & 0.01 \\
\hline Chromium & 0.003 & 0.1 & 1.0 & 0.05 \\
\hline Cobalt & $<0.01$ & 0.05 & 1.0 & -.. \\
\hline Copper & 0.05 & 0.2 & 0.5 &.-- \\
\hline Fluoride & 1.5 & 2.0 & $\ldots$ & -.. \\
\hline Iron & 1.8 & 5.0 & $--\cdot$ & -.. \\
\hline Lead & $<0.03$ & 5.0 & 0.1 & 0.05 \\
\hline Lithium & 10 & 2.5 & -- & -- \\
\hline Manganese & 0.12 & 0.2 & -- & -.. \\
\hline Mercury & $<0.0001$ & -.. & 1 & 0.002 \\
\hline Molybdenum & 0.02 & 0.01 & $\ldots$ &.- \\
\hline Nickel & $<0.03$ & 0.2 & $\ldots$ & $\ldots$ \\
\hline Selenium & 0.004 & 0.02 & 0.05 & 0.01 \\
\hline Silver & $<0.02$ & -- & -- & 0.05 \\
\hline Vanadium & $<0.03$ & -.- & 0.1 & -.- \\
\hline Zinc & $<0.2$ & ... & ..- & ... \\
\hline
\end{tabular}

were small and reflected varying amounts of dilution of base flow by runoff from precipitation. These are not considered significant.

- The chemical constituents in ground water at individual locations varied slightly during the year. These variations are not considered significant, as they are within normal seasonal fluctuations. Chemical analyses of water from supply well $\mathrm{FH}-1$ at TA-57 indicate that this water is probably from two sources with slightly different chemical quality and temperature. The water is moderately hard and contains relatively high concentrations of silicate, calcium, and magnesium that may cause scale problems in the distribution system.

\section{REFERENCES}

1. W. D. Purtymun, F. G. West, and W. H. Adams, "Preliminary Study of the Quality of Water in the Drainage Area of the Jemez River and Rio Guadalupe," Los Alamos Scientific Laboratory report LA-5595-MS (April 1974).

2. W. D. Purtymun, W. H. Adams, and J. W. Owens, "Water Quality in Vicinity of Fenton Hill Site, 1974," Los Alamos Scientific Laboratory report LA-6093 (December 1975). 
3. W. D. Purtymun, W. H. Adams, A. K. Stoker, and F. G. West, "Water Quality in Vicinity of Fenton Hill Site, 1975," Los Alamos Scientific Laboratory report LA-6511-MS (September 1976).

4. W. D. Purtymun, "Geology of the Jemez Plateau West of the Valles Caldera," Los Alamos Scientific Laboratory report LA-5124-MS (February 1973).

5. W. D. Purtymun, F. G. West, and R. A. Pettitt, "Geology of Geothermal Test Hole GT-2, Fenton Hill Site, July 1974," Los Alamos Scientific Laboratory report LA-5780-MS (November 1974).
6. Standard Methods for the Examination of Water and Wastewater, American Public Health Assoc., Inc., New York, 13th Ed. (1971).

7. US Environmental Protection Agency, Proposed Criteria for Water Quality, Vol. 1 (1973).

8. US Environmental Protection Agency, "Water Programs, National Interim Primary Drinking Water Regulations," Federal Register, Vol. 40, No. 248 (December 24, 1975). 
APPENDIX A

\section{SURFACE WATER QUALITY}

\begin{tabular}{|c|c|c|c|c|c|c|c|c|c|c|c|c|c|c|c|}
\hline \multirow{2}{*}{ Leation" } & \multicolumn{3}{|c|}{$\begin{array}{c}\text { Sulphur Creek } \\
\text { above } \\
\text { San Antonio Creek (F) }\end{array}$} & \multicolumn{3}{|c|}{$\begin{array}{c}\begin{array}{c}\text { Jemez River } \\
\text { below }\end{array} \\
\text { Battleship Rock (J) } \\
\end{array}$} & \multicolumn{3}{|c|}{$\begin{array}{c}\text { San Antonio Creek } \\
\text { above } \\
\text { Sulphur Creek (N) }\end{array}$} & \multicolumn{3}{|c|}{$\begin{array}{c}\text { Rio Guadalupe } \\
\text { above } \\
\text { Jemez River (Q) }\end{array}$} & \multicolumn{3}{|c|}{ 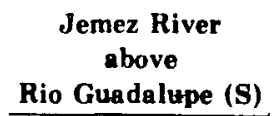 } \\
\hline & $4 / 27$ & $8 / 4$ & $11 / 19$ & $4 / 27$ & $8 / 4$ & $11 / 19$ & $4 / 27$ & $8 / 4$ & $11 / 19$ & $\overline{4 / 27}$ & $8 / 4$ & $11 / 18$ & $4 / 27$ & $8 / 4$ & $11 / 19$ \\
\hline \multicolumn{16}{|l|}{ Chemical Analyses (m/ll) } \\
\hline Silica & 33 & 38 & 39 & 38 & 49 & 56 & 47 & 49 & 58 & 13 & 19 & 26 & 40 & 48 & 55 \\
\hline Calcium & 36 & 48 & 54 & 16 & 16 & 13 & 16 & 16 & 13 & 27 & 42 & 47 & 45 & 48 & 45 \\
\hline Magnesium & 9 & 12 & 9 & 5 & 4 & 3 & 9 & 5 & 3 & 5 & $\mathbf{5}$ & 9 & 4 & 7 & 5 \\
\hline Sodium & 20 & 15 & 24 & 13 & 16 & 20 & 10 & 14 & 16 & 5 & 9 & 16 & 56 & 66 & 87 \\
\hline Carbonate & 0 & 0 & 0 & 0 & 0 & 0 & 0 & 0 & 0 & 0 & 0 & 0 & 0 & 0 & 0 \\
\hline - icarbonate $\left(\mathrm{HCO}, \approx \mathrm{CeCO}_{3}\right)$ & 4 & 8 & 14 & 50 & 72 & 70 & 58 & 76 & 54 & 86. & 120 & 176 & 144 & 176 & 162 \\
\hline Sulfate & 102 & 142 & 156 & 10.7 & 10 & 7.4 & 6.2 & 3.9 & 10.3 & 2.7 & 4 & 1.4 & 10.1 & 13 & 10.7 \\
\hline Chloridé & 31 & 16 & 33 & 6 & 4 & 10 & 2 & 2 & 5 & $<1$ & 2 & 8 & 75 & 90 & 50 \\
\hline Fluoride & 0.4 & 0.4 & 0.3 & 0.6 & 0.6 & 0.7 & 2.5 & 0.6 & 1.0 & 0.5 & 1.2 & 0.6 & 0.6 & 0.7 & 1.1 \\
\hline Nitrate & $<0.1$ & 0.1 & $<0.1$ & 0.1 & $<0.1$ & $<0.1$ & 0.1 & 0.1 & $<0.1$ & 0.1 & $<0.1$ & $<0.1$ & 0.1 & $<0.1$ & $<0.1$ \\
\hline Total Dissolved Selich & 212 & 194 & 258 & 148 & 174 & 159 & 150 & 184 & 161 & 112 & 244 & 192 & 386 & 468 & 300 \\
\hline Total Hardness (as $\mathrm{CaCo}$ ) & 125 & 170 & 172 & 60 & 56 & 46 & 75 & 60 & 46 & 88 & 130 & 154 & 128 & 150 & 132 \\
\hline Specific Conductance ( $\mu \mathrm{rmho} / \mathrm{cm}$ ) & 460 & 290 & 480 & 180 & 170 & 170 & 170 & 160 & 155 & 190 & 230 & 330 & 600 & 670 & 710 \\
\hline pH & 6.9 & 4.3 & 7.5 & 7.6 & 7.7 & 7.7 & 7.6 & 7.2 & 7.7 & 7.9 & 8.1 & 8.0 & 7.8 & 8.0 & 8.3 \\
\hline Temperature $\left({ }^{\circ} \mathrm{C}\right)$ & 4 & 11 & 0 & 7 & 15 & 3 & 7 & 14 & 0 & 11 & 20 & 6 & 14 & 13 & 7 \\
\hline Discharge estimated ( $/ / 8)$ & 60 & 100 & 6 & 550 & 520 & 225 & 75 & 350 & 140 & 420 & 550 & 55 & 550 & 350 & 140 \\
\hline
\end{tabular}

- For location Fig. 1 
APPENDIX A (cont)

\begin{tabular}{|c|c|c|c|c|c|c|c|c|c|c|c|c|c|}
\hline \multirow{2}{*}{$\frac{\text { Location" }}{\text { Date of Collection (1976) }}$} & \multicolumn{4}{|c|}{$\begin{array}{c}\text { Jemez River } \\
\text { below } \\
\text { Rio Guadalupe (R) }\end{array}$} & \multicolumn{3}{|c|}{$\begin{array}{c}\text { Rio Cebolla } \\
\text { below } \\
\text { Lake Fork Canyon }(T)\end{array}$} & \multicolumn{3}{|c|}{ Redondo Creek (U) } & \multicolumn{3}{|c|}{$\begin{array}{c}\text { Sulphur Creek } \\
\text { above } \\
\text { Redondo Creek(U) }\end{array}$} \\
\hline & $4 / 2$ & $4 / 27$ & $8 / 4$ & $11 / 19$ & $4 / 27$ & $8 / 5$ & $11 / 19$ & $4 / 27$ & $8 / 4$ & $11 / 19$ & $4 / 27$ & $8 / 4$ & $11 / 19$ \\
\hline \multicolumn{14}{|l|}{ Chemical Analyses (mg/l) } \\
\hline Silica & 10 & 28 & 44 & 54 & 32 & 35 & 36 & 30 & 31 & 38 & 43 & 52 & 46 \\
\hline Calcium & 35 & 37 & 48 & 46 & 16 & 20 & 19 & 23 & 20 & 24 & 50 & 98 & 74 \\
\hline Magnesium & 7 & 2 & 5 & 7 & 3 & 4 & 4 & 4 & 7 & 3 & 10 & 13 & 10 \\
\hline Sodium & 42 & 39 & 57 & 82 & 10 & 12 & 12 & 21 & 11 & 21 & 15 & 24 & 27 \\
\hline Carbonate & 0 & 0 & 0 & 0 & 0 & 0 & 0 & 0 & 0 & 0 & 0 & 0 & 0 \\
\hline Bicarbonate $\left(\mathrm{HCO}_{1}\right.$ as $\mathrm{CaCO}$ ) & 130 & 116 & 168 & 181 & 76 & 80 & 80 & 28 & 44 & 44 & 0 & 0 & 0 \\
\hline Sulfate & 13 & 8.5 & 11 & 8.2 & 1.9 & $<1$ & $<1$ & 8.5 & 10.7 & 6.6 & 205 & 354 & 317 \\
\hline Chloride & 58 & 45 & 78 & 91 & 2 & 2 & 3 & 58 & 22 & 59 & 3 & 10 & 10 \\
\hline Fluoride & 0.4 & 0.8 & 0.5 & 1.2 & 0.7 & 0.4 & 0.5 & 0.2 & 1.1 & 0.2 & 0.4 & 0.4 & 0.5 \\
\hline Nitrate & $<0.1$ & 0.1 & $<0.1$ & $<0.1$ & 0.1 & $<0.1$ & $<0.1$ & $<0.1$ & $<0.1$ & $<0.1$ & $<0.1$ & 0.3 & $<0.1$ \\
\hline Total Dissolved Solids & 366 & 268 & 476 & 428 & 134 & 126 & 127 & 240 & 242 & 186 & 368 & 752 & 462 \\
\hline Total Hardness (as $\mathrm{CaCO}_{2}$ ) & 118 & 100 & 140 & 144 & 56 & 67 & 66 & 74 & 80 & 72 & 164 & 300 & 226 \\
\hline Specific Conductance $(\mu \mathrm{mho} / \mathrm{cm})$ & 390 & 390 & 580 & 680 & 200 & 190 & 170 & 310 & 190 & 280 & 510 & 1200 & 770 \\
\hline $\mathrm{pH}$ & 8.3 & 7.8 & 7.9 & 8.0 & 7.4 & 7.9 & 8.0 & 7.3 & 7.5 & 7.5 & 4.3 & 3.3 & 3.6 \\
\hline Temperature $\left({ }^{\circ} \mathrm{C}\right)$ & $\cdots$ & 13 & 21 & 6 & 18 & 15 & 7 & 3 & 12 & 0 & 4 & 11 & 4 \\
\hline Discharge estimated $(\ell / \mathrm{s})$ & $\ldots$ & 1000 & 850 & 200 & 85 & 225 & 85 & 30 & 30 & 5 & 15 & 50 & 2 \\
\hline
\end{tabular}

- For location see Fig. 1. 


\section{APPENDIX B}

\section{GROUND WATER QUALITY}

\begin{tabular}{|c|c|c|c|c|c|c|c|c|c|c|c|c|c|c|c|}
\hline \multirow{2}{*}{$\begin{array}{l}\text { Location" } \\
\text { Date of Collection (1976) }\end{array}$} & \multicolumn{3}{|c|}{$\begin{array}{c}\text { Water Supply } \\
\text { Jemez Springs; } \\
\text { Church Canyon } \\
\text { East and West (JS-2, -3) } \\
\end{array}$} & \multicolumn{3}{|c|}{$\begin{array}{c}\text { Water Supply, Jemez } \\
\text { Springs; Seno and Agua } \\
\text { Durme Springs (JS-4, -5) }\end{array}$} & \multicolumn{3}{|c|}{$\begin{array}{c}\text { Water Supply } \\
\text { La Cueva; } \\
\text { Horseshoe Springs (4) } \\
\end{array}$} & \multicolumn{3}{|c|}{$\begin{array}{c}\begin{array}{c}\text { Limestone Spring } \\
\text { West of Battleship Rock } \\
(\mathrm{JF}-1)\end{array} \\
\end{array}$} & \multicolumn{3}{|c|}{$\begin{array}{c}\text { Mineral and Thermal } \\
\text { Spring. Soda } \\
\text { Dam (JF-5) } \\
\end{array}$} \\
\hline & $4 / 27$ & $8 / 4$ & $11 / 19$ & $4 / 27$ & $8 / 4$ & $11 / 19$ & $4 / 27$ & $8 / 5$ & $11 / 19$ & $4 / 27$ & $8 / 4$ & $11 / 19$ & $4 / 27$ & $8 / 4$ & $11 / 18$ \\
\hline \multicolumn{16}{|l|}{ Chemical Analyser (mg/l) } \\
\hline Silica & 63 & 32 & 72 & 73 & 74 & 77 & 57 & 80 & 83 & 42 & 48 & 46 & 45 & 40 & 45 \\
\hline Calcium & 16 & 16 & 12 & 17 & 14 & 13 & 11 & 16 & 10 & $128^{\circ}$ & 140 & 19 & 56 & 316 & 111 \\
\hline Magnesium & 3 & 12 & 5 & 4 & 5 & 4 & 3 & 5 & 3 & 12 & 15 & 13 & 23 & 32 & 23 \\
\hline Sodium & 17 & 15 & 16 & 13 & 15 & 15 & 16 & 17 & 16 & 208 & 305 & 365 & 1115 & 620 & 950 \\
\hline Carbonate & 0 & 0 & 0 & 0 & 0 & 0 & 0 & 0 & 0 & 0 & 0 & 0 & 0 & 0 & 0 \\
\hline Bicarbonate ( $\mathrm{HCO}$, as $\left.\mathrm{CaCo}_{2}\right)$ & 70 & 68 & 70 & 72 & 72 & 70 & 66 & 68 & 63 & 504 & 550 & 466 & 680 & 1190 & 612 \\
\hline Sulfate & $<1$ & 12 & 1.2 & $<1$ & 1.7 & 0.4 & 2.1 & 6.6 & $<1$ & 23 & 28 & 24 & 30 & 37 & 37 \\
\hline Chloride & 10 & 2 & 6 & 3 & 2 & 7 & 3 & 2 & 4 & 285 & 374 & 441 & 1400 & 1330 & 1470 \\
\hline Flunride & 0.5 & 0.5 & 0.6 & 0.4 & 0.5 & 0.5 & 0.4 & 0.3 & 0.2 & 2.0 & 1.7 & 3.1 & 2.1 & 2.2 & 3.2 \\
\hline Nitrate & 0.2 & 0.1 & 0.2 & 0.1 & $<0.1$ & 0.2 & 0.2 & $<0.1$ & 0.2 & 0.3 & $<0.1$ & 0.1 & $<0.1$ & $<0.1$ & 0.1 \\
\hline Total Dissolved Solids & 166 & 163 & 168 & 184 & 178 & 174 & 164 & 124 & 176 & 1094 & 1252 & 1168 & 3298 & 3560 & 3286 \\
\hline Total Hardness (as $\mathrm{CaCO}$ ) & 52 & 90 & 52 & 58 & 58 & 50 & 40 & 60 & 38 & 370 & 410 & 100 & 236 & 920 & 372 \\
\hline Specific Conduct ance $(\mu \mathrm{mho} / \mathrm{cm})$ & 190 & 160 & 170 & 170 & 160 & 160 & 150 & 150 & 140 & 1850 & 2110 & 2310 & 5540 & 6000 & 5500 \\
\hline $\mathrm{pH}$ & 7.7 & 7.4 & 7.7 & 7.5 & 7.6 & 7.6 & 7.9 & 7.7 & 7.7 & 7.8 & 7.3 & 8.3 & 7.6 & 7.6 & 7.1 \\
\hline Temperature $\left({ }^{\circ} \mathrm{C}\right)$ & 12 & 20 & 8 & 15 & 25 & 14 & 15 & 19 & 17 & 16 & 17 & 15 & 47 & 47 & 46 \\
\hline
\end{tabular}


APPENDIX B (cont)

\begin{tabular}{|c|c|c|c|c|c|c|c|c|c|}
\hline \multirow{2}{*}{ Lacation } & \multicolumn{3}{|c|}{$\begin{array}{l}\text { Cold Spring, Lake } \\
\text { Fork Canyon (3i) }\end{array}$} & \multicolumn{3}{|c|}{$\begin{array}{c}\text { Hofhein Flowing } \\
\text { Well }(27)\end{array}$} & \multirow{2}{*}{$\begin{array}{c}\begin{array}{c}\text { San Antonio } \\
\text { Hot Spring }(R V-2)\end{array} \\
8 / 4\end{array}$} & \multirow{2}{*}{$\begin{array}{l}\text { Spence Spring } \\
\frac{(R V-4)}{8 / 4}\end{array}$} & \multirow{2}{*}{$\begin{array}{c}\begin{array}{c}\text { McCauley Spring } \\
(R V-5)\end{array} \\
8 / 5\end{array}$} \\
\hline & $4 / 27$ & $8 / 5$ & $11 / 19$ & $4 / 27$ & $8 / 5$ & $11 / 19$ & & & \\
\hline \multicolumn{10}{|l|}{ Chemical Amalyses $(m g / l)$} \\
\hline Silica & 46 & $\cdots$ & 51 & 57 & 67 & 66 & 74 & 66 & 54 \\
\hline Calcium & 13 & 15 & 13 & 27 & 31 & 27 & 4 & 7 & 12 \\
\hline Magnesium & 3 & 6 & 2 & 9 & 7 & 8 & 5 & 2 & 7 \\
\hline Sodium & 10 & 12 & 11 & 110 & 102 & $1: 30$ & 22 & 45 & 19 \\
\hline Carbonate & 0 & 0 & 0 & 0 & 0 & 0 & 0 & 0 & 0 \\
\hline Bicarbonate $\left(\mathrm{HCO}_{2}, \mathrm{CaCO}_{3}\right)$ & 62 & 68 & 57 & 382 & 353 & 366 & 48 & 120 & 80 \\
\hline Sulfate & 1.4 & $\ldots$ & 0.4 & 2.7 & 3.7 & 1.2 & 0.2 & 15 & 1.4 \\
\hline Chloride & 3 & 3 & 5 & 4 & 10 & 6 & 2 & 4 & 4 \\
\hline Flumide & 1.2 & 0.7 & 0.8 & 1.1 & 1.0 & 0.8 & 0.5 & 0.6 & 0.8 \\
\hline Nitrate & 0.3 & 0.1 & 0.2 & 0.8 & $<0.1$ & $<0.1$ & 0.2 & 0.1 & 0.2 \\
\hline Total Dissolved Solida & 138 & 126 & 142 & 470 & 364 & 498 & 142 & 294 & 143 \\
\hline Total Hardness (as $\mathrm{CaCo}_{2}$ ) & 44 & 63 & 42 & 104 & 105 & 102 & 30 & 28 & 60 \\
\hline Specific Conductance $(\mu \mathrm{mho} / \mathrm{cm})$ & 150 & 150 & 135 & 690 & 760 & 670 & 120 & 280 & 170 \\
\hline pH & 8.1 & 7.7 & 7.7 & 7.9 & 7.9 & 7.9 & 6.8 & 7.8 & 7.1 \\
\hline Temperature $\left({ }^{\circ} \mathrm{C}\right)$ & 10 & 11 & 10 & 21 & 22 & 16 & 40 & 40 & 31 \\
\hline
\end{tabular}

- For location see Pr. 1. 
Arengiotx 8 (nent)

Loentien ${ }^{a}$

Date of Conthen (I\%)

Hotr

Chemical Analyees ( $\mathrm{mg} / \mathrm{l}$ )

Silica

Calcium

Magnesium

Sodium

Carbonate

Bicarbonate $\left(\mathrm{HCO}_{3}\right.$ as $\left.\mathrm{CaCO}_{3}\right)$

Sulfate

Chibride

Fluoride

Nitrate

Total Dissolved Solids

Total Hardnes (as $\mathrm{CaCO}_{3}$ )

Specific Conductance $(\mu \mathrm{mho} / \mathrm{cm})$ $\mathrm{pH}$
Supply WA FH-1, TA-57

\begin{tabular}{|c|c|c|c|c|c|c|}
\hline $7 / 1^{b}$ & $7 / 26$ & $7 / 29$ & $7 / 26$ & $7 / 27$ & $7 / 27$ & $11 / 19$ \\
\hline--- & $12: 00$ & $13: 30$ & $21: 00$ & $06: 00$ & $13: 15$ & --- \\
\hline 28 & 42 & 49 & 54 & 66 & 61 & 70 \\
\hline 16 & 28 & 32 & 32 & 36 & 36 & 31 \\
\hline 7 & 12 & 7 & 7 & 2 & 2 & 4 \\
\hline 68 & 24 & 20 & 14 & 14 & 14 & 11 \\
\hline 0 & 0 & 0 & 0 & 0 & 0 & 0 \\
\hline 180 & 112 & 116 & 108 & 116 & 112 & 107 \\
\hline 73 & 18 & 20 & 3.3 & 13 & 15 & 0.6 \\
\hline 8 & 8 & 8 & 6 & 8 & 8 & 7 \\
\hline 0.7 & 0.2 & 0.2 & 0.4 & 0.1 & 0.1 & 0.2 \\
\hline 0.2 & $<0.1$ & $<0.1$ & 0.2 & $<0.1$ & 0.1 & $<0.4$ \\
\hline 344 & 98 & 120 & 18 & 102 & 104 & 202 \\
\hline 70 & 120 & 110 & 110 & 100 & 100 & 94 \\
\hline 400 & 250 & 245 & 240 & 240 & 240 & 240 \\
\hline 8.3 & 8.1 & 7.9 & 7.5 & 8.0 & 8.0 & 1.6 \\
\hline
\end{tabular}

"For location see Fig. 1.

'Sample - Test Water Depth 118.9 m. 


\section{APPENDIX C}

\section{WATER QUALITY OF PONDS, TA-57}

\begin{tabular}{|c|c|c|c|c|c|c|}
\hline \multirow{2}{*}{$\begin{array}{c}\text { Location } \\
\text { Date of Collection (1976) }\end{array}$} & \multicolumn{2}{|c|}{$\begin{array}{c}\text { Upper Pond } \\
\text { (GTP-1) }\end{array}$} & \multicolumn{2}{|c|}{$\begin{array}{c}\text { Middle Pond } \\
\text { (GTP-2) }\end{array}$} & \multicolumn{2}{|c|}{$\begin{array}{c}\text { Lower Pond } \\
\text { (GTP-3) }\end{array}$} \\
\hline & $8 / 5$ & $11 / 19$ & $8 / 5$ & $11 / 19$ & $8 / 5$ & $11 / 19$ \\
\hline \multicolumn{7}{|l|}{ Chemical Analyses (mg/l) } \\
\hline Silica & 115 & 94 & 144 & 36 & 136 & 190 \\
\hline Calcium & 48 & 9 & 32 & 14 & 40 & 2 \\
\hline Magnesium & 10 & 2 & 12 & 3 & .7 & 1 \\
\hline Sodiu & 380 & 81 & 280 & 114 & 365 & 930 \\
\hline Carbonate & 0 & 0 & 0 & 0 & 0 & 334 \\
\hline Bicarbonate $\left(\mathrm{HCO}_{3}\right.$ as $\left.\mathrm{CaCO}_{3}\right)$ & 204 & 142 & 236 & 148 & 208 & 1380 \\
\hline Sulfate & 297 & 204 & 101 & 42 & 162 & 153 \\
\hline Chloride & 360 & 15 & 340 & 114 & 450 & 351 \\
\hline Fluoride & 4 & 1.0 & 4.6 & 2.5 & 5.6 & 50 \\
\hline Nitrate & 0.2 & 8.9 & 0.1 & 0.1 & 0.2 & 0.2 \\
\hline Total Dissolved Solids & 1472 & 392 & 1201 & 384 & 1606 & 3018 \\
\hline Total Hardness (as $\mathrm{CaCO}_{3}$ ) & 160 & 30 & 130 & 50 & 130 & 8 \\
\hline Specific Conductance $(\mu \mathrm{mho} / \mathrm{cm})$ & 2200 & 2125 & 1800 & 705 & 2220 & 3890 \\
\hline $\mathrm{pH}$ & 7.8 & 8.2 & 7.5 & 7.9 & 7.7 & \\
\hline
\end{tabular}




\section{APPENDIX D}

TRACE METAL ANALYSES OF WATER AT FENTON HILL SITE, 1976

\begin{tabular}{|c|c|c|c|c|c|c|c|c|}
\hline \multirow[b]{3}{*}{ Date of Collection } & \multirow{2}{*}{\multicolumn{2}{|c|}{$\begin{array}{l}\text { Upper Pond } \\
\text { (GTP-1) }\end{array}$}} & \multirow{2}{*}{\multicolumn{2}{|c|}{$\begin{array}{c}\text { Lower Pond } \\
\text { (GTP-3) } \\
\end{array}$}} & \multicolumn{2}{|c|}{ Test Holes } & \multirow{2}{*}{\multicolumn{2}{|c|}{$\begin{array}{c}\text { Lower Pond } \\
\text { (GTP-3) }\end{array}$}} \\
\hline & & & & & \multirow{2}{*}{$\begin{array}{c}\overline{\mathrm{EE}-1^{\mathrm{a}}} \\
7 / 21 \\
\mathrm{mg} / \ell \\
\end{array}$} & \multirow{2}{*}{$\begin{array}{c}\mathrm{GT}-2^{\mathrm{b}} \\
11 / 7 \\
\mathrm{mg} / \ell \\
\end{array}$} & & \\
\hline & $\begin{array}{l}7 / 21 \\
\mathrm{mg} / \ell \\
\end{array}$ & $\begin{array}{r}9 / 23 \\
\mu \mathrm{g} / \mathrm{l} \\
\end{array}$ & $\begin{array}{c}7 / 21 \\
\mathrm{mg} / \ell \\
\end{array}$ & $\begin{array}{r}9 / 23 \\
\mu \mathrm{g} / \ell \\
\end{array}$ & & & $\begin{array}{l}11 / 7^{\mathrm{c}} \\
\mathrm{mg} / \ell\end{array}$ & $\begin{array}{l}11 / 7^{\mathrm{d}} \\
\mathrm{mg} / \mathrm{\ell}\end{array}$ \\
\hline Aluminum & $<1$ & -.. & $<1$ & ... & $<1$ & 0.06 & 0.19 & 2 \\
\hline Antimony & -.- & $<200$ & --- & $<200$ & $\ldots$ &.-- & $<0.3$ & $<0.3$ \\
\hline Arsenic & -.. & $<500$ & -.. & $<500$ & ... & -.. & $<0.5$ & $<0.5$ \\
\hline Barium & --- & 200 & --- & 200 & $\ldots$ &.-- & 0.15 & 0.2 \\
\hline Beryllium & --- & $<3$ & --- & $<3$ & -.- & -.- & $<0.01$ & $<0.01$ \\
\hline Bicarbonate & 360 & -- & 260 & -.. & 240 & 185 & 5 & 7 \\
\hline Bismuth & --- & $<10$ & --- & $<10$ & -.. & -.. & $<0.1$ & $<0.1$ \\
\hline Boron &.-- & 80000 & -.. & 8000 & --- & -.. & 5 & 5 \\
\hline Cadmium & $\ldots$ & $<100$ & $\ldots$ & $<100$ & --- & -.. & $<1$ & $<1$ \\
\hline Calcium & 32 &.-- & 35 & -.- & 23 & 2.4 & 9 & 42 \\
\hline Carbonate & 0 & -.. & 0 & -- & 0 & -. & 0 & 0 \\
\hline Chlorine & 501 & -- & 501 & $\ldots-$ & 10 & 400 & 300 & 170 \\
\hline Chromium & --- & $<3$ & --. & $<3$ & $\ldots$ & -.. & 0.001 & 0.003 \\
\hline Cobalt & --- & $<3$ & --- & $<3$ & $\ldots$ & -.. & $<0.01$ & $<0.01$ \\
\hline Copper & --- & 20 & --- & 20 &.-- & ... & 0.15 & 0.05 \\
\hline Fluoride & 11 & $\ldots$ & 10 &.-- & 1 & 12 & 2 & 1.5 \\
\hline Gallium &.- & $<10$ &.-- & $<10$ &.-- & $\ldots$ & -.. &.- \\
\hline Germanium & --- & $<30$ &.-- & $<30$ &.-- & -.. & 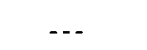 & -.- \\
\hline Hydrogen Sulfide & --- &.-- &.-- & $\ldots$ & -- & $<1$ & $<1$ & $<1$ \\
\hline Iron & 7 & 5000 & 6 & 5000 & 0.3 & 2.0 & 2.8 & 1.8 \\
\hline Lead &.- & 60 & $\cdots$ & 20 &.- &.-- & $<0.03$ & $<0.03$ \\
\hline Lithium & -- & 1000 & -.- & 1000 & $\ldots$ & $\ldots$ & 10 & 10 \\
\hline Magnesium & 0.02 &.-- & 0.03 &.-- & 5 & 1.9 & 2.2 & 4.6 \\
\hline Manganese & $\cdots$ & 50 &.- & 60 & $\ldots$ & 0.01 & 0.03 & 0.12 \\
\hline Mercury & -.- &.-- & -.. & $\ldots$ & -.. &.-- & --- & $<0.0001$ \\
\hline Molybdenum & -- & 40 &.-- & 40 & -.. & -.. & $<0.02$ & 0.02 \\
\hline Nickel & --. & $<5$ & -.- & $<5$ & -.. & -.- & $<0.03$ & $<0.03$ \\
\hline Niobium & $\ldots$ & $<30$ & ... & $<30$ & -.- & $\ldots$ & --- & -.. \\
\hline Phosphorus &.-- & $<30$ & -- & $--\cdot$ & -.. &.-- & $<1$ & $<1$ \\
\hline Phosphate & 0.3 & --- & 0.4 &.-- & 0.5 & 0.16 & 0.18 & 0.15 \\
\hline Potassium & 45 & -.. & 44 & -.- & 8 &.- & 50 & 40 \\
\hline Selenium & -.. & $<1000$ & $-\cdots$ & $<1000$ & $\ldots$ & --- & -- & 0.004 \\
\hline Silica & 203 & --- & 206 &.- & 46 & 219 & 160 & 85 \\
\hline Silver & --- & $<10$ & --- & $<10$ & $\ldots$ & -- & $<0.02$ & $<0.02$ \\
\hline Sodium & 470 & --- & 460 & $\cdots$ & 63 & -- & 200 & 150 \\
\hline Strontium & --- & 400 & $\cdots$ & 400 & $<20$ & $\cdots$ & 0.4 & 0.4 \\
\hline Sulfate & 145 & $\ldots$ & 185 & -- & -.. & -.. & -.- & -.- \\
\hline Tin & -.. & $<30$ & -.- & $<30$ & $\ldots$ & $\ldots$ & $<0.1$ & $<0.1$ \\
\hline Vanadium & --- & $<5$ & -.. & $<5$ & $\ldots$ &.-- & $<0.03$ & $<0.03$ \\
\hline Zinc & ... & 150 & --- & 150 & $\ldots$ & $\ldots$ & $<0.2$ & $<0.2$ \\
\hline Zirconium & --. & $<3$ & --- & $<3$ & $\ldots$ & --- & $\ldots$ & -.. \\
\hline
\end{tabular}

${ }^{a}$ Quality of Water injected into Test Hole EE-1.

${ }^{\mathrm{b}} \mathrm{Quality}$ of injected water returned from test hole GT-2.

${ }^{c}$ Quality of water after treatment.

${ }^{\mathrm{Q}}$ Quality of water released to canyon. 